\title{
'They all here call me índio': Indigenous identification and the criminal justice system in Northern Minas Gerais
}

\author{
Rodrigo Arthuso Arantes Faria' \\ 'University of British Columbia (UBC), Vancouver, British Columbia, Canada
}

\begin{abstract}
The article analyses the interaction between the criminal justice system and persons of the Xakriabá Indigenous people facing criminal prosecution in the Manga district in Northern Minas Gerais. To do so, I draw on the material gathered in the fieldwork I carried out in the region in early 2020, as well as on current legislation, selected jurisprudence from the Supreme Court, and documents produced by the bodies responsible for the criminal and prison policies in Brazil. I argue in the paper that the category of 'Indigenous person' mobilized by state agents differs from that conceived by the Xakriabá themselves, and that this dissonance often implies the lack of ethnic recognition of these persons throughout the criminal process and the failure to record their presence in official prison management documents. As a consequence, what is seen is the violation of the right to self-identification and the non-enforcement of legal guarantees granted to all Indigenous persons by the Brazilian legal system.
\end{abstract}

Keywords: Xakriabá People; Indigenous self-identification; Ethnic decharacterization; Criminal Justice System; Minas Gerais. 


\section{'Todo mundo aqui me chama de índio': autoidentificação indígena e o sistema de justiça criminal no norte de Minas Gerais}

\section{Resumo}

$\mathrm{O}$ artigo analisa a interação entre o sistema de justiça criminal e indígenas do povo Xakriabá que respondem a processos criminais na comarca de Manga, no norte de Minas Gerais. Para isso, utilizo o material colhido no trabalho de campo que realizei na região no início de 2020, bem como a legislação vigente, a jurisprudência selecionada do Supremo Tribunal Federal e os documentos produzidos pelos órgãos responsáveis pelas políticas criminal e prisional no Brasil. Argumento no artigo que a categoria de "indígena" mobilizada por agentes estatais difere daquela concebida pelos próprios Xakriabá, e que dessa dissonância frequentemente decorrem a falta de reconhecimento étnico dessas pessoas durante o processo penal, e do registro de sua presença nos documentos oficiais da administração penitenciária. Como consequência, o que se vê é a violação do direito à autoidentificação e a não aplicação das garantias legais concedidas a todas as pessoas indígenas pelo ordenamento jurídico brasileiro.

Palavras-Chave: Povo Xakriabá; Autoidentificação indígena; Descaracterização étnica; Sistema de Justiça Criminal; Minas Gerais.

\section{Aquí todos me llaman indio': la autoidentificación indígena y el sistema de justicia penal en el norte de Minas Gerais}

\section{Resumen}

El artículo analiza la interacción entre el sistema de justicia penal y los indígenas del pueblo Xakriabá que responden a las demandas penales en el distrito de Manga, en el norte de Minas Gerais. Para lograrlo, utilizo el material reunido en el trabajo de campo que realicé en la región a principios de 2020, así como la legislación vigente, la jurisprudencia seleccionada del Tribunal Supremo y los documentos producidos por los órganos responsables de las políticas penales y penitenciarias en el Brasil. En el artículo se sostiene que la categoría de "indígena" movilizada por los agentes estatales difiere de la concebida por los propios Xakriabá, y que esta disonancia suele ser resultado de la falta de reconocimiento étnico de estas personas durante el proceso penal, y del registro de su presencia en los documentos oficiales de la administración penitenciaria. En consecuencia, lo que se observa es la violación del derecho a la autoidentificación y la inaplicación de las garantías jurídicas que el sistema jurídico brasileño otorga a todos los pueblos indígenas.

Palabras clave: Pueblo Xakriabá; Autoidentificación indígena; descaracterización étnica; Sistema de justicia penal; Minas Gerais. 


\title{
'They all here call me índio': Indigenous identification and the criminal justice system in Northern Minas Gerais
}

\author{
Rodrigo Arthuso Arantes Faria
}

\section{Setting the stage}

In this paper I articulate how preconceptions about Indigenous peoples acts as a mediator of the interactions between the criminal justice system, its agents and individuals from the Xakriabá Indigenous people accused of having committed a conduct established by law as criminal. My analysis is built on elements I have already discussed in my Master's Dissertation (Faria, 2021), and is based primarily on the fieldwork I carried out in the state of Minas Gerais, in February and March 2020, when I read through the case files, immersed myself in the Court routine, interviewed police, judicial and prison agents, as well as incarcerated Indigenous persons, their families and the Lideranças [leaders] of the Xakriabá people. The article is also informed by the analysis of the instruments of criminal and carceral policies at the federal and state level, and by a brief review of the legislation on the intersection of criminal and Indigenous matters.

Whether through formal procedural dialectics in the lawsuits, or face-to-face exchanges along the investigation and trial proceedings, a legal dispute is set when state 'indigeneity regimes' (Silva, 2016) and Indigenous own conceptions about themselves confront each other, which presupposes, at both individual and institutional levels, the interaction of the ways in which 'Indigenous beings' conceive and present themselves with the modes by which 'being Indigenous' is socially represented and preconceived. The main point of this paper is then to articulate how a social representation (Moscovici, 1984) of Indigenous peoples have been historically constructed, categorized and reproduced, the influence they have on the performance of the agents of the criminal justice system and the reverberations on the long and winding road of recognition, protection and promotion of Indigenous rights.

\section{In the beginning there were none... then there was a woman... soon after, her brother}

Januária is a city of just over 65 thousand inhabitants located in the Northern region of the state of Minas Gerais, in the Southeast of Brazil. On the banks of River São Francisco, it is about 80 kilometres South of São João das Missões. Between Januária and São João das Missões, is the city of Itacarambi; overlapping the limits of Itacarambi and São João das Missões, the Xakriabá Indigenous Land ${ }^{1}$. About 6ookm away from there, still in Brasilia, in the initial movements of collecting preliminary information about the region, I searched the National Penitentiary Department (DEPEN) database to check if there were, on the official records, any Indigenous persons imprisoned in Minas Gerais. There were none ${ }^{2}$. I then called directly the Januária, Itacarambi and Manga Prison Units on the telephone. In Manga, contrary to what the statistics said, I was told that there were somewhere between five and ten Indigenous persons incarcerated there, though the precise number was not known.

\footnotetext{
1 Due to the state judicial administration, the municipality of Itacarambi is covered by the jurisdiction of the Januária Judicial District, and the municipality of São João das Missões, by the Manga Judicial District, around $25 \mathrm{~km}$ North of Missões.

2 Database for December 2019 available at https:|/tinyurl.com/y8l $5 \mathrm{gk} 8 \mathrm{z}$ (accessed 10 June 2020).
} 
In the phone conversation with the Director of the Januária Prison, I was informed that there was an Indigenous woman in the female wing of the Itacarambi Prison - however there, in Januária, there were no Indigenous person to be found. In contact with the Itacarambi Prison, they confirmed her presence. Informing them that I would be in the region for the next month, I asked for permission to enter the unit, scheduled an interview with the Director, and questioned if I could interview the woman, if she so agreed. Everything was answered positively and the visit scheduled for the following days. Due to the scarce availability of bus lines from Brasilia, I got off at Januária, a regional hub where buses depart for the surrounding smaller cities, such as Itacarambi and São João das Missões. There, on the appointed day, I contacted the Itacarambi Prison to confirm the visit and the interviews. None of my seven calls were answered. I gave up for the moment and decided to go to the Januária Courthouse, find the case files of this woman, talk to the Judge responsible for monitoring the execution of her sentence, and also to the Public Defender that was representing her in the case. Before talking to the Magistrate, I spoke with the Registrar of the Court of Criminal Executions, who gave me the number and some bureaucratic details of the case - she, the Registrar, was really surprised to learn, at that very moment, that the sentenced woman was an Indigenous person. Moments later, speaking with the Judge in the courtroom, in a brief interval between hearings, I started asking if he remembered the case of the Xakriabá woman incarcerated in Itacarambi. His response was firm and sincere: 'I'm finding out now that you are telling me.'3 'And now that you know, is there anything to do?', I later asked him. 'Well, I'll look into it...', he replied. This precise dialogue also occurred in the conversation with the Public Defender, who assured me that he would adopt 'all applicable measures' for the case.

Whether they looked into it or not, I don't know. I know that, days later, in the city of São João das Missões, while talking, in the Military Police Headquarters, with the Lieutenant responsible for policing the municipality, a woman entered the room and asked him to sign her Term of Commitment, a formal requirement for provisional release from jail. Without looking the policeman or me in the eyes, always with her head down, she didn't say 'hi' or 'bye', just asked for the signature and, obtaining it, hurriedly left. As soon as she left, the Lieutenant told me, while complaining about the woman's 'rudeness', that she was the Indigenous woman who, until days earlier, had been incarcerated in Itacarambi. I couldn't find her again. What I found, though, through the Lieutenant himself, is that a brother of hers, also an Indigenous person, was imprisoned in Januária - where, according to the statistics and the Director of the Prison, there were no Indigenous prisoners.

This incident is a good example of how the state of Minas Gerais treats Indigenous persons, especially in its criminal justice system. It reveals both sides of the single coin of the 'politics of non-recognition' (Miller, 2003) in the state - and, other studies indicate, in Brazil as a whole (ABA and PGR 2008; Silva 2014; Baines 2016; Menezes 2017): it reveals the apparent absence of Indigenous persons in the official records, and their precarious, informal presence in the prison system. It is not, however, the non-recognition of an entire people to the right to exist and to be officially recognized as a discreet Indigenous collective. It is a modality in which non-recognition operates the violation of rights on an individual basis, from person to person, from criminal case to criminal case.

3 All provisions of Brazilian law and all conversations and field interviews cited here are originally in Portuguese, therefore, the transcriptions contained in the following chapter are all my own translations of them. Likewise, as the county is small and the criminal matter is, itself, quite delicate, the names of my interlocutors are also kept anonymous, which is why I indicate, instead, a random letter of the alphabet to designate them (as in 'Agent Z' or in 'Xakriabá A'). 


\section{The Indigenous person within the law}

Before addressing how the criminal justice system and the Xakriabá people interact, it is necessary to briefly review the legal framework that underpins this interaction. There are four normative texts that contain provisions related to Indigenous rights in the criminal sphere in Brazil4: Resolution no. 287 of the National Council of Justice (CNJ), of June 252019 (CNJ 2019); Indian Statute, instituted by the 1973 Law 6,001 (Brasil 1973); Convention 169 of the International Labour Organization, incorporated in the Brazilian legal system in 2004 through Decree 5,051 (Brasil 2004); and the 1988 Federal Constitution (Brasil 1988).

The most recent of them, Resolution no. 287, was edited and published by CNJ at the end of inter-agency discussions that included, due to their expertise in Indigenous issues, the Brazilian official indigenist agency, the National Indian Foundation (FUNAI). It is not a law in strict legislative sense, but an internal norm of orientation for the Judiciary that establishes procedures for the treatment of Indigenous persons and provides guidelines to ensure their rights in the criminal justice system. As stated in its Article 2, the Resolution is to be applied 'to all persons who identify themselves as Indigenous, Brazilian or not, speaking both Portuguese and native languages, regardless of their place of residence'. Although timidly, it updates the normative reference for Judiciary action towards Indigenous defendants, providing important mechanisms such as the need for acknowledgement and record of the Indigenous self-identification in the case files, the intervention of interpreters and anthropology experts, and the consultation with the Indigenous community on the execution of sentences in the aldeias [Indigenous villages], such as house arrest and the semi-freedom regime.

The Indian Statute, for its turn, is marked by the coexistence of the tutelage and the integration paradigms. In its first article, it establishes as its purpose to 'progressively and harmoniously' integrate Indigenous peoples into the national communion. To integrate, in the Statute's sense, is to deprive Indigenous peoples of their socio-cultural expressions and assimilate them into the surrounding society as citizens without any ethnic markers (Heemann, 2017). Until full integration takes place, Article 7 establishes tutelage for 'non-integrated Indians's, special protection given to people relatively incapable of autonomously exercising civilian acts, which, in the case of Indigenous persons, should be exercised by the Union through FUNAI. The measure of integration is given by Article 4, in which Indigenous peoples are distinguished by the categories of 'isolated', 'in the process of integration' and 'integrated', with the inclusion/exclusion criteria fixed in the frequency and intensity of contact with non-Indigenous society, associated with the maintenance or abandonment of their own cultural traits. In criminal matters, Articles 56 and 57 proposes guidelines in line with this integrationist thinking, the former stipulating that 'the penalty must be reduced and in its application the Judge will also take into account the degree of integration of the Indigenous person', and the latter, that the penalties of imprisonment and detention should preferably be carried out at the regional FUNAI headquarters.

The 1988 Constitution broke, formally at least, with the integrationist and tutelar paradigm of the Indian Statute, and recognized the autonomy of Indigenous peoples in order to extend its protection to their 'social organization, customs, languages, beliefs and traditions', included their mechanisms for punishing criminal conducts, holding the offender accountable and making due reparation to the victim, i.e., their own jurisdiction and criminal law (Villares, 2010: 22). This aspect, associated with the decision not to define in the text fixed criteria for identifying Indigenous persons and peoples, led scholars to consider that Article 231 of

\footnotetext{
4 Also noteworthy, within international law, Article 34 of the United Nations Declaration on the Rights of Indigenous Peoples (UN 2007) and Article XXII of the American Declaration on the Rights of Indigenous Peoples (OAS 2016), which recognize, respectively, the right of Indigenous peoples to maintain their 'juridical systems or customs' and their 'laws and legal systems', provided that 'in accordance with international human rights standards'.

5 Throughout this paper, the terms 'Indian' and 'Indigenous person' have similar meanings. The differentiation I make is solely to distinguish between the Portuguese expressions índio [Indian] and indigena [Indigenous person].
} 
the Constitution, hierarchically superior, tacitly revokes the degrees of integration provided for in the Indian Statute, expanding its scope to contemplate all persons and peoples that identify themselves as Indigenous, regardless of the contact regime they maintain with non-Indigenous society (Araújo, Leitão 2012; Pereira 2012). In this sense, Articles 56 and 57 of the Indian Statute, although inscribed in a legal diploma prior to the constitutional order, can still be interpreted in accordance with it. Simply put, once the 'degrees of integration' have been abandoned, the subjective cause of mitigation of the sanction and differentiated sentence regimes should be extended to all Indigenous people (Souza Filho, 1999: 113-114; Villares 2009: 311; Castilho, 2019: 138-139).

If the Constitution did not stipulate the criteria that would serve as a guideline for determining who would be the peoples to whom it was intended, ILO Convention 169 did so: self-identification. Self-identification on the side of Indigenous peoples, of course, and on the side of national states, the recognition, not the granting, of the Indigenous identification that is being declared. Particularly to criminal matters, Articles 9 and 10 refer to what was said above about the recognition of the criminal administration proper to the Indigenous people, expressly stating that 'the customs of these peoples in regard to criminal matters shall be taken into consideration by the authorities and Courts dealing with such cases.' Another important measure, in Article 10, says that 'preference shall be given to methods of punishment other than confinement in prison.'

When considering all the normative provisions together, it is possible to note the intertwining of two issues that, in fact, permeates most of the discussions on Indigenous rights in Brazil (and elsewhere): the first concerns the definition of who is legally, officially recognized as Indigenous, and the second refers to the compatibility of Indigenous sociocultural expressions, such as normative and justice systems, with that of the State. On the latter, the Convention places the compatibility with universal Human Rights as the limit of the extension of Indigenous practices: if Indigenous laws and procedures do not contradict basic human rights, or, according to the Statute, 'do not have a cruel or infamous character', they are, in thesis, perfectly applicable. The question of identity, though, is understandably more delicate (Oliveira, 2003; Pacheco de Oliveira, 2016; Cunha, 2017). To the extent of the present discussion, it is worth briefly resuming the note made above, perhaps the central point of this chapter.

In line with ILO Convention 169, I argue that there should be no criteria - legal, conventional or constitutional - for the identification of Indigenous peoples other than self-identification. However, specifically within the criminal justice system, self-identification has been shown to be insufficient to have ethnic identification formally recognized and the rights derived from it properly enforced. The opportunities for self-declaration are routinely suppressed by Police Officers, Judges and Prison Agents, and when not suppressed, it is questioned, if not solemnly ignored. This is particularly the case with Indigenous persons who, regardless of the time and intensity of social interactions they maintain with the surrounding society, absorbed some of its customs and appropriated some of its signs (Menezes, 2016). When they are under the intervention of the criminal justice system, comes to effect an unofficial, unnecessary verification of the self-identification based mostly on phenotypic characteristics or exotic culture traits. This illegal 'ethnicity check' is mobilized precisely to deny Indigenous persons, first, official recognition as such, and second, the legal enforcement of their specific rights. This is precisely the case, as I discuss throughout this paper, with the Xakriabá people.

In the district of Manga, the Xakriabás are considered 'integrated Indians', and 'integrated Indians' are only entitled to the rights of ordinary citizens and nothing more. This is said expressly by the agents, such as Agent L, who considers that 'the non-integrated [Indigenous person], has to have rights, I think he has to have differentiated treatment, but the integrated, I don't think so'. Or Agent R. When I asked Agent R if a supposedly integrated Indigenous person is still an Indigenous person, he answered me firmly and sincerely: 'in practice, which is what we're dealing with here, no'. Or, finally, Agent $\mathrm{P}$, who told me that the information that a certain defendant is an Indigenous person is absolutely irrelevant, 'because if he's fully integrated, if he's aware of what's going on, and he simply says he's indigenous, I don't see why he should be treated differently'. 
This apparent unrestricted dissemination of the idea that 'integrated' Indigenous persons are not included in the legal - and ontological - category, and therefore not entitled to Indigenous rights, raises the question of what is meant by such a category of Indigenous. Or, to put it another way: to what conception of an Indigenous person is the concrete figure of an 'integrated' defendant opposed, in order to verify whether he or she satisfies the constitutive criteria of a legitimate and legally valid indigeneity?

\section{The Amazonian paradigm}

As stated above, criminal justice system agents and the non-Indigenous inhabitants of the Manga and Missões region do not recognize Xakriabá people as 'real' Indigenous people, being common in their accounts, including those of lawyers, idiosyncratic variations of the same rationale that affirms that 'those Indians are not Indians', which denotes that they recognize, at first, the self-identification of a certain collective inhabiting the region as being an Indigenous collective ('those Indians'), and soon after, contrasting them with their representation of what would be 'truly' Indigenous, disqualifying them as such ('they are not Indians').

This rationale is readily incorporated by newcomers. The first interviews I conducted in the city of Manga were with some of the personnel of the Civil Police, the institution responsible, roughly speaking, for investigating crimes. There, I talked with the Delegate, with the Registrar and with the Investigators on duty that week. The first aspect that caught my attention was that the body of Investigators, which numbered five people at the time, was composed almost exclusively of young agents, recently admitted to the corporation and recently arrived in Manga. The exceptions were the Registrar and one of the agents, with whom I talked separately for a longer time. Due to the volume of work and the regular rush of a Police Station, the first interview was carried out collectively, in the Investigators' room, all at the same time, in a conversation that, if followed the script that had been established for it, was constantly interrupted by people entering the room, phones ringing and diversions sparked by memories of random cases they had worked on. Then to be restarted. The first point raised by them would be, at first, a cold shower for my purposes: they had not yet answered any occurrences, and therefore, had not acted directly in cases involving Xakriabás. In any case, they still had their impressions about them.

The first of these impressions: it is very complicated to attend occurrences in the Indigenous Land, 'because of the Indians themselves, because their resistance is very great', said one of them. The second impression, about the most common crimes that happen there: environmental crimes, illegal possession of firearms and domestic violence. When I asked if Indigenous persons should receive any differentiated treatment, with the emphasis that 'differentiated' did not mean 'privileged', the answer of one agent stood out: 'Indians here in the North of Minas ... they do not have much of that peculiar characteristic of the índio amazonense [Amazonian Indian]', stating that 'they use this Indigenous cape very often to get a lot, to have government support', concluding saying that 'I do not believe that they are in fact Indigenous, only in the nomenclature that they call themselves as such.' On the specific topic of what would define certain people as Indigenous, one of them tells me that 'it is not a physical aspect' - without, however, concluding the reasoning.

Walking to the end of the conversation, which started with the information that none of them had yet carried out actions in the Indigenous villages, I was told by one of them that 'when you enter the aldeias, what you see most is stolen luxury cars... it is completely different than you might traditionally find in other places, in the North... those other places.' As he was speaking, he suddenly remembered of the time when he worked at the Federal Police in the city of Montes Claros, when the actions he saw happening in the Xakriabá territory were related to environmental crimes, illegal hunting and fishing outside the permitted period, to which he added: 'they use this Indigenous carcass to commit crimes, I think.' As, unlike the Xakriabá (who 
wore either a cape or a carcass of real Indigenous persons), the Amazonians Indigenous peoples have their 'peculiar characteristic', I asked if they, the Amazonians, should receive different treatment if they committed crimes. The answer, with everyone's agreement, was firm and sincere: 'I don't know, I've never been there.'

The reference to the North of Brazil, or more precisely, to the Amazon, is constant among the agents of the criminal justice system and regional interlocutors. In this sense, Agent W told me that 'I thought that the Xakriabá people would live like people in the North, in the North of Brazil... I thought it would be something, people living in ocas [huts], things like that'. Agent $\mathrm{N}$, in our conversation, while indicating the characteristics of a legitimate Indigenous person, pointed to where he or she is found: 'For me an Indigenous person is straight hair, oriental features, like an Amazonian Indian, this is Indian to me'. A woman I interviewed in Januária, who jokingly told me that she had already visited every aldeia in Brazil, stated emphatically: 'The real Indian is in the North, in the Vale do Javari, there you will see, it is different, it is beautiful, there are real Indians there... in Mato Grosso, the Kayapó...'.

In the definition that was presented to me by this interlocutor in Januária, a genuine Indigenous person is 'when he is the son of an Indian father, an Indian mother, who has a whole blood flow'. In a similar sense, Agent $M$ describes a 'real' Indigenous person as those 'with little contact, who lives more on the reservation and limits himself to living like an Indian ... following the traditions and everything'. Agent W, on the other hand, defines an Indigenous person as 'one who lives in the jungle, one who doesn't really know our norms, they wear those accessories, paintings, you know'. The most detailed characterization, however, was perhaps that provided by Agent L, who told me that 'the guy [an Indigenous one] is dark brown, with straight hair, a square face, a slightly flat nose, an individual that doesn't have a beard'. And concludes: 'I have never seen a hairy Indian.'

Amazonian Indigenous people being the paradigm of indigeneity for criminal agents cannot really be seen as a surprise. In fact, there is a historical-political background that plays an important role in the construction of this Indigenous ideal type. It goes back to the first Portuguese alliances at the time of the invasion in the 16th century, and culminates with the current authoritarian demand for conformity with an Indigenous figuration that is based more on a cynical colonial abstraction than on a real knowledge of Indigenous realities of 21st century Brazil. I elaborate a little better on these considerations below.

\section{The creation of the image, the dominance of the imaginary}

Tupi-speaking Indigenous peoples were the first to establish permanent contact with European invaders, and not surprisingly, the most well-known and described over the first centuries of occupation. Spreading across territories that extended from the present states of Maranhão (to the Northeast) and Santa Catarina (to the South), they soon became the centre of reference for the colonizers regarding the whole of populations that inhabited these lands - a phenomenon largely reflected on what Manuela Carneiro da Cunha called 'Tupi ethnocentrism' (2012: 48), that encompassed, albeit in a subsidiary way, the image and presence of Guarani peoples. This fact caused the Tupi basic ontological distinction - us (Tupi) and them (Tapuia) - to be incorporated into the colonial lexicon of the early sixteenth century to distinguish the first allies from the first enemies of the Portuguese settlers.

The imaginary around native people in general was, nevertheless, unequivocally ambiguous, they being either a degenerate, savage and cannibal version of the real humans (Europeans), yet still capable of conversion to faith and civility, or irrevocably inferior, inconvertible and, therefore, liable to enslavement or extermination (Pacheco de Oliveira and Freire, 2006). As the colonial domination deepened, this basic operational cleavage was reformulated in order to differentiate Indigenous persons based on their acceptance or refusal to domestication: 
on the one hand, 'friendly Indians', sedentarized, Christianized and, for that matter, considered free; on the other, the 'heathen castes' (Monteiro, 200o), the unsubmissive savage, the enemy, over whom war and slavery weighed heavily. These contrasting markers have also determined the legal treatment given to each of the segments, what will be maintained, not without its intricacies, throughout the whole 'tortuous and contradictory' Brazilian colonial period (Perrone-Moises, 1992: 117). This essentially variable images, and its no less variable nominations, were possible to be constructed and socially represented due essentially to stereotypes, and, as Ronald Raminelli argues, 'guaranteed the fixation of the Indian in the western imagination, functioned as decoders capable of translating the American reality and making the communication between such disparate worlds viable' (1996: 165).

The nineteenth century, following the turbulent path of its predecessors, printed profound political upheavals in the history of Brazil: from colonized periphery to autonomous Republic, an Empire most of the time. If variable in its political forms, in relation to Indigenous peoples the period did nothing but to update and reproduce the classificatory oppositional poles of colonial times, categorizing Indigenous persons into 'tame' and 'brave' (Cunha, 1992: 136). At the turn of the century, the Brazilian nation-state sought to assert itself, politically through the republican movement, scientifically with the absorption of positivist scientism, and economically, by the expansion of the frontiers of occupation and the irresolute belief in progress. At the sociological intersection of this mixture, stands the birth of the "fable of the three races" (Ramos, 2018), the founding myth of Brazilian national identity, and in its artistic expression, the Indianismo movement, a tropical appropriation of European romanticism responsible for popularizing the image on which the 'collective imaginary' about Indigenous peoples would rest from then on (Tacca, 2011). This image was based less on ethnographic observations of the present than on an idealized projection of the past ${ }^{6}$, and its exaltation as a cultural symbol of the country, attributing to Indigenous peoples a dubious notion of 'nobility, heroic strength and imposing character', is situated in a chronological compass with the beginning of the extermination that advanced throughout the twentieth century over Indigenous lands and populations (Coli, 2013).

The presage of an invigorating polysemy of Indigenous images and of a duality of Indigenous categories was seen in the 1987-1988 National Constituent Assembly, responsible for crafting the new Brazilian Federal Constitution after the dictatorial regime (1964-1985). Perhaps the most emblematic - and problematic parliamentary proposal discussed during the proceedings was the one that established that the rights provided for in the chapter dedicated to Indigenous peoples 'do not apply to Indians with a high level of acculturation, who maintain a constant conviviality with national society and who do not inhabit Indigenous Lands'. Such a formulation, that clearly draws a line of separation that presupposes not a difference in degree - one being more Indigenous than the other - but of nature - one is Indigenous, the other is not ${ }^{7}$ - did not appear in the Draft of the Subcommittee on Blacks, Indigenous Populations, Disabled People and Minorities, nor in the Social Order Commission, but it was insistently advocated in later moments. To get an idea of how hard was the battle against this particular article, let us remember that it was first presented in article 305 of the 1st Substitute for the Rapporteur; maintained in article 264 of the 2nd Substitute for the Rapporteur; reaffirmed in article 271 of the Substitute for amendments to the Plenary approved by the Systematization Commission;

\footnotetext{
6 Interesting to note, with Cunha (1992: 136), the crystallization of this division also in the preferential representation of the time, which distinguished, on the one hand, the Tupi-Guarani, 'the good Indian and, conveniently, the dead Indian', and on the other, the Botocudos, the antithetical image of the Tupi-Guarani, 'a living Indian, the one against war is fought'.

7 The proposal goes back to at least two past legislative moments: the 1973 Indian Statute that establishes that 'integrated' Indigenous persons must be 'emancipated', so that they are placed outside the protection of the Brazilian state's Indigenous agency, and the 1978 Decree proposal by which 'integrated' Indigenous persons would cease to be considered Indigenous, thus passing to the civilian regime of ordinary Brazilian citizenship, regardless of their ethnic affiliation.
} 
reformulated by the Amendments of the Centrão as Article 266, establishing that 'the rights provided for in this chapter only apply to Indians who effectively inhabit Indigenous Lands and do not have a high degree of acculturation'; to finally have its suppression suggested by an Amendment by Deputy Fábio Feldman - which was accepted in the Final Text for the Second Round of Discussion and Voting9.

Although excluded from the final text of the Constitution, the clashes during the Constituent Assembly indicate the persistence of a political image still present in the Brazilian social imaginary, one that separates Indigenous persons and peoples who are still Indigenous, and those who are not anymore. And who are, in the twenty-first century, still considered Indigenous in Brazil? Well, it seems that the game has turned to the peoples from the Amazon. While coastal Tupi-Guarani peoples became the image and likeness of the Brazilian Indigenous person until at least the twentieth century, those from the North contributed almost nothing to it (Cunha, 2012: 28). Today, however, Amazonian Indigenous peoples are the indisputable standard bearers of the genuine Brazilian Indigenous identity, the region playing the double role of the ideational source and concrete geographical space for the production and reproduction of indigeneity in Brazil.

Not by coincidence, the dominant multicultural imaginary regarding Indigenous peoples not only reflects a peculiar taste for the exotic of current global sensibility, but goes hand in hand with environmental concerns - almost exclusively focused on the Amazon. A clear example can be found in the survey carried out by the Instituto Socioambiental (ISA) and the Brazilian Institute of Public Opinion and Statistics (IBOPE) in 200o, not only by the answers of the interviewees, but also by the questions of the interviewers ${ }^{10}$. Indeed, questions like 'Do the Indians conserve nature and live in harmony with it?' and 'Should the Indians have the right to continue living in the jungle according to their customs?', certainly refer to a very specific type of Indigenous person, that one who apparently lives in an idyllic relationship of harmony with 'the jungle'. Likewise, the agreement of almost 50\% of the interview respondents with the idea that in the future the Indigenous people 'will continue on their lands and preserve their culture', and the disagreement of almost $70 \%$ of them on the question 'The Indians must be ready to leave the jungle and live like us?', indicate, once again, if not a bias from the researchers, a very widespread image among Brazilians of the inexorable relationship between 'Indian' and 'jungle' and between 'jungle' and 'Indian culture'.

\section{Xakriabás are those who live as Xakriabás}

Residing and resisting in the northernmost limits of the state of Minas Gerais, almost on the border with the state of Bahia, the Xakriabá are a people from the sertões [hinterlands], from the drought (Da Silva, 2014). Currently, about 8,867 Indigenous persons (Siasi/Sesai 2014)" inhabit the continuous Xakriabá (approved in 1987) and Xakriabá-Rancharia (added in 2003) Indigenous Lands. Beyond the boundaries of the demarcated land, there are also Xakriabá living in the city of São João das Missões and in neighbouring municipalities, such as Itacarambi and Januária, and also in Montes Claros - the largest city in the region. Beyond regional boundaries, they live in Belo Horizonte, Brasília, São Paulo and many other cities throughout Brazil, driven, in general, by economic and educational opportunities. In fact, 'there are Xakriabá all over the world', tells me Xakriabá E, a Liderança of the people.

\footnotetext{
8 Supraparty parliamentary bloc created at the end of the first year of the National Constituent Assembly from 1987-1988 and still active today in the National Congress. Although it does not have a uniform ideological political program, it is located at the centre-right of the Brazilian political spectrum, bringing together conservative-thinking politicians.

9 The information regarding the Constituent Assembly was taken from the Annals of the Constituent, available on the website of the Federal Senate at https:/tinyurl.com/ybw6gsap (accessed 29 May 2020).

10 The survey was published in the series Indigenous Peoples in Brazil (1996-200o), edited by Carlos Alberto Ricardo and published by Instituto Socioambiental in 2000.

11 Information taken from the Instituto Socioambiental website, available at https://tinyurl.com/y77vmcaz (accessed o6 July 2020).
} 
Their history, like that of so many other Indigenous peoples in Brazil, is marked by the traumatic process of contact with non-Indigenous society, established with the arrival of the fronts of economic, political and religious expansion (Santos, 1997). Initially in constant movement, driven by conflicts with other Indigenous collectives, also with explorers and farmers, involuntarily placed in aldeias with other peoples and mixed with 'whites' (mostly from the Northeast, from Bahia and Pernambuco, and more recently, with people from São Paulo), the Xakriabá are characterized, and recognize themselves, as 'mixed Indians' (Pacheco de Oliveira, 2016). In their history, the struggle for the recognition and demarcation of their traditional territory is a powerful cohesion factor, which both organizes the sociality and disposition of the aldeias, and it is still used today as a parameter in the choice of their Lideranças (Roberto Oliveira, 2008).

Besides being a material support for daily life, the land is at the same time an immemorial reference and an index of the collective intersubjectivity that establishes the Xakriabá as a people. 'The awareness of their territory is very strong among the Xakriabá,' notes Sônia de Almeida Marcato, reinforcing that 'the very definition of who is or is not Xakriabá also goes through the declamation that we constantly heard in the field: 'he was born and raised here, on our land' (1987: 14). Or, as Xakriabá E told me: 'we consider that if he was born and raised and follows the respect, respecting the tradition, I think that he is an Indigenous person'. The Xakriabá $G$ agrees with this idea as he told me that 'the only thing is that we were born and brought up here, our father and grandparents are all from here, that is why they say that we are Indigenous, we were born and brought up in the reserve.'

However, the ordering of this intersubjectivity is heterogeneous, and is not guided by fixed criteria. To be 'born and raised' is a sufficient but not necessary condition for individual inscription in the collective. As the Xakriabá E told me, 'Here we have people from outside married to Xakriabá. They come in and follow the path: born outside, but from that day they make the commitment, the marriage, and follow the culture of the Xakriabá, we consider them' [to be Xakriabá]. Twisting this perspective, once Xakriabá, the absence from the territory does not imply exclusion from the group: it becomes an 'índio desaldeado [an Indigenous person living outside the aldeia], he doesn't live in the village anymore, but he is still us'. And once again turning the perspective around: 'who leaves, comes back... and continues to follow the culture' (all according to Xakriabá E).

This kind of fluidity regarding the criteria for inclusion and belonging to the collective ends up giving rise to a prejudiced interpretation of the diversity found among the members of the Xakriabá people. In the region, it is common to designate them either as apurados [genuine] or não-apurados [non-genuine]. This distinction is made not only by criminal justice agents and regional interlocutors, but also by the Xakriabá themselves, who recognize some relatives as apurados, and others as not. Here, two fundamental points must be raised regarding how regional agents and the Xakriabá understand these categories.

The first is that, for criminal agents and regional interlocutors, the figure of the apurado is a socially fabricated representation of an idealized Indigenous figure supposedly endowed with a 'pre-colonial authenticity' (Povinelli, 1998) and geo-referenced to the Northern region of Brazil. For the Xakriabá people, however, the apurado Indigenous person is an image of themselves, produced and reproduced based on certain elements - knowledge of traditions, a certain circumspect posture (Costa e Santos, 2010) - that they understand as characteristic of their own people, but that is differentially shared by its members.

The second point concerns the não-apurados. For the agents of the criminal justice system, in general, these are not, in fact, Indigenous persons. Some said so directly, like Agent $\mathrm{N}$ : 'there is nothing Indigenous about them'. Others, in a rhetorical juggling act, said that although they are Indigenous persons, they would not be entitled to Indigenous people's rights - or any special treatment. For the Xakriabá people, however, even those who are identified as não-apurados are, indeed, Xakriabá, and enjoy recognition and belonging to the group like any other. 'Within our consciousness, we know that there are no Indians, half-Indians, or non-genuine-Indians, 
for us it makes no difference,' said Xakriabá G. The coexistence and even interchangeability between the Xakriabás apurados and não-apurados is not simply an expression of the people's openness to otherness, but is also related to historical, economic, and political struggles to protect and maintain their integrity and territory - and the integrity of their territory.

The recognition of the impact of these struggles on the reproduction of the cultural expressions of the people is present, for example, in the remarks of the Xakriabá Rogério Lopes, who points out that 'there was a time when the older people, our grandfathers, our grandmothers, were forbidden to use the culture. Then they couldn't pass it on to their children, so the culture was lost. But then we saw that it is our identity, so we are in search of it again and we are here' (in Suarez and Tavares, 2020). The articulation between tradition and constant struggle is also mobilized by the Xakriabás Ariclenes Ferreira dos Santos and Aparecido Rodrigues de Oliveira, in the joint study developed in the Tenda/Rancharia village. Pulling the thread through the voices of the 'elders', they associate the 'numbing of a certain part of the culture' with two primary vectors, an internal one (population growth) and an external one (pressure from the ranchers). They also comment on 'how important our relationship is with the land, the animals, the sacred places, the traditional knowledge and the roots that are created with the cosmos, which are all related to the land' (Ferreira dos Santos and Oliveira, 2017: 44).

The historical processes of harmful interaction between the Xakriabá people and the region's nonIndigenous inhabitants are, however, unknown to the majority of the agents of the criminal justice system in Manga - and their present reality is just ignored. One of the two Prosecutors responsible for conducting criminal proceedings in the Manga Judicial District, just over six months in office at the time, had not yet gone to the Indigenous Land. The other one, after three and a half years in office, hadn't either - because of the distance, he justified, and the difficulty of access. The lack of concern about the past and the present, the lack of a minimal knowledge about the socio-cultural organization of the Xakriabá people ends up becoming a very sensitive feature of these public agents, on whom rests the responsibility of conducting and judging lawsuits involving Indigenous rights and persons. The Xakriabá know - and feel - this as a fact.

Talking to Xakriabá E about the difficult relationship between Xakriabá people and their non-Indigenous neighbours, the answer came firm and sincere: 'Indigenous persons, outside the aldeia, are frowned upon... everything wrong is on the Indigenous person's account.' Far from being an exclusive feature of São João das Missões, the perception also extends to other cities in the region, because 'we walk around Januária, Itacarambi, in all these neighbouring cities, we are free to walk around', tells me Xakriabá E, 'but when one sees that there goes an Indigenous person... they think that an Indigenous person is an animal, it seems that, for them, it is like this, a different thing.'

This perception is also shared by Xakriabá G. Right in the first minutes of the conversation with him, he emphatically states: 'To begin with, one Prosecutor arrives, does not even come to know the region first [referring to the Indigenous Land], to know the differences, right? There are Prosecutors who arrive, enter and leave, and don't even know the reality here. And the Judges, the same. Not to mention the Delegate, right?' Right. None of the two Prosecutors from the Manga Judicial District, until that moment, had stepped into the Xakriabá Land. Neither the Judges, nor the Delegate. 'That is why', he continued, 'that I am concerned, because they are not taking into account that there is the Xakriabá people here, that there is a people who belongs to the region'. And concludes with a rightful question: 'At the very least, as professionals, they should be aware of this, right?'.

A practical consequence of this indifference towards the Xakriabá - almost a fifth of the population under the jurisdiction of the Judicial District of Manga - is that without the concrete reference to these people, the image of the Indigenous person that will guide the performance of the criminal justice system will be sought in a generic, virtual representation, constructed - although changeable - according to the convenience of the 
occasion. The search for this image, as argued before, is unnecessary since the Federal Constitution recognizes Indigenous autonomy and ILO Convention 169 establishes self-identification as the fundamental criteria for the identification of 'interested peoples'. This means that Indigenous peoples are guaranteed the freedom to the full enjoyment of their modes of being, to be established and exercised according to their own premises and aspirations, in no way conditioned to a return to cultural practices of the past and, in effect, open to the constant re-elaborations of daily life practices. They are, therefore, constitutionally and conventionally guaranteed the right to establish their own criteria for belonging, and these criteria per se should be the only ones valid for the purpose of their legal recognition as Indigenous.

\section{If there are no imprisoned Indians, there are Indians imprisoned ${ }^{12}$}

Entering a Brazilian prison as a prisoner cannot be considered particularly difficult. Brazil today has about 773,00o people taken to prison units ${ }^{13}$, qualifying as the third largest prison population in the world (behind only the USA and China) - and consistently on the rise since at least the 20oos (Zackseski, 2016). As a researcher, the procedure for applying, obtaining and entering prison units in the state of Minas Gerais is a little more bureaucratic. There are at least five forms to be filled out, accompanied by the research project and the researcher's personal identification documents, and submitted for deliberation by the State Department of Justice and Public Security (Sejusp-MG). Once the procedure has been completed and the entry authorization has been granted, there is a second check by the prison administration, in addition to protocol security procedures.

As an Indigenous person, it seems easier to enter prison units than prison statistics. There are three databases maintained by official bodies that use the race/ethnicity field as a filter to identify specific sections of the prison population. According to their most updated versions, the only one that reports the existence of Indigenous prisoners in Minas Gerais is the one maintained by the National Council of the Public Ministry (CNMP), called 'Prison System in Numbers' ${ }^{14}$. Despite not having updated figures for the year 2020, it registered the existence of 06 (six) Indigenous prisoners in the Manga Prison in the second quarter of 2019. The System is not free of inconsistencies, however. And the numbers themselves, if the databases are analysed together, even in a superficial view indicate the fragility of their collection, feeding and systematization protocols. The CNMP, for example, indicates a total of 737 (seven hundred and thirty-seven) in the second quarter of 2019. The National Penitentiary Information Survey (Infopen) maintained by DEPEN, referring to December 2019, records the existence of 1390 Indigenous prisoners ${ }^{15}$, almost double that held by the CNMP. In turn, the National Bank for Prison Monitoring (BNMP) implemented by the National Council of Justice (CNJ), accounts for only 244 (two hundred and forty-four) ${ }^{16}$ in August 218. The official database of the state of Minas Gerais does not have consolidated figures for the Indigenous prison population. However, in a consultation made directly with Sejusp-MG through a formal request made under the Brazilian Access to Information Law, the answer provided was firm and sincere: 'There are no Indigenous persons [in jail] in the state at the moment.'

The purpose of my visit to the Manga Prison was, then, to hear from the Indigenous persons about their experience in prison, and from prison officers about how the system thinks and acts in relation to these people, and from that try to give a little more sense to inconsistent statistical numbers.

\footnotetext{
12 I thank Lídia Lacerda for calling attention to the word play, which unpretentiously says a lot about the object of this work.

13 Data presented on the World Prison Brief (WPB) digital platform, maintained by the Institute for Crime \& Justice Policy Research (ICPR) and Birkbeck University of London, available at https:/|tinyurl.com/yzhq4qtj (accessed 7 July 2020)

14 Interactive platform maintained by CNMP available at https://inyurl.com/y8a6jvrr (accessed 10 June 2020).

15 Updated survey published by DEPEN on its official website, available at https://tinyurl.com/y85j936e (accessed 10 June 2020).

16 Report for the month of August 2018, last published, is available for consultation on the CNJ website at https:/tinyurl.com/y8shwtht (accessed 10 June 2020).
} 
Information about prisoners, as told me Agent $\mathrm{N}$, the prison officer responsible for the screening and admitting of prisoners entering the Manga Prison, is collected right at the moment of their admission and promptly inserted in the Prison Management System (Sigpri). Sigpri's information, for its turn, will be used to fill in DEPEN's form, which will then serve as the basis for Infopen - the official database of the Federal Government on the prison population. 'And how is this information collected, including the person's race or ethnicity?', I asked Agent N. 'Asking... to the guy himself... we ask everyone...', he replied. 'They never asked any of this, no, the first time anyone is asking is today,' said Xakriabá F, 32 years old Xakriabá man imprisoned in Manga, when I asked him if he has identified himself as an Indigenous person. 'If you ask me, I tell you... but they never asked', said 20 years old Xakriabá B to the same question. The three agreed on one point, though, that regardless of self-declaration, it is known that the prisoner is Indigenous when his origin is the city of São João das Missões. 'Here they know us', said Xakriabá F.

In fact, many of the prison agents in Manga claim to know the members of the Xakriabá people that end up in the prison. Agent V, for instance, states that 'sometimes we already know, for that reason there'. The reason he refers to is, in reality, twofold: the fact that he already knows the Xakriabá people ('as I know a lot of them') and the verification with their declared place of residence ('when you insert their address, most of the times it even says 'Indigenous area', or 'rural area of São João das Missões', or even 'Indigenous village'). This logic is also presented by Agent N, as he tells me that 'most of the time we already know [that the person being admitted to the prison is Indigenous], as the district is small, sometimes we already know... usually when it comes from the São João das Missions region'.

Statistics suggest a different scenario, however: the absence of these people in the records indicates that, if they are known to be Indigenous, they are not being acknowledged as such. As said above, according to official data, there were no Indigenous persons in custody in Manga; according to its Director, by telephone, there were between five and ten; at the beginning of the visits to the unit, there were six, five of whom agreed to talk to me; at the end of the second day of visiting there were seven, since one of them indicated another Xakriabá who was also serving time there. In addition to the seven in Manga and the woman in Itacarambi, there is a ninth Xakriabá imprisoned in the region, in the Januária Prison, as mentioned by the Lieutenant in São João das Missões.

These Xakriabá individuals form an informal population within these prison units: the agents know who almost all of them are, so much so that they indicated six of them for the interviews; the other detainees, according to the Indigenous men themselves, also know that they are Indigenous, so much so that they commonly nickname them indio; and the Xakriabá men are, and claim to be, Indigenous. However, neither in the federal nor in the state databases their ethnic identification is recognized. Nor in legal proceedings, where it would be possible to mobilize those Indigenous rights and guarantees mentioned above, there is the acknowledgement that the lawsuit is filed against an Indigenous person. The need for it is justified by the fact that not only the denial of the recognition of ethnic identification is, in itself, a concrete violence, but that precisely from this violence derives the denial of the application of those rights and guarantees. Simply put, if there is no Indigenous person, there is no Indigenous right.

In this sense, the Xakriabá are not being recognized or registered as the Indigenous persons they are and declare to be, due to prejudice and because they are the lawful subjects of certain rights that the criminal justice system is not willing to observe. This conclusion, if not obvious, is at least expected, considering that the criminal justice system is the space par excellence, within the Brazilian state sphere, of the 'restriction and violation of rights', of the 'reproduction of inequality and deconstruction of subjectivities', which is, in short, the 'dimension of social exclusion' (Andrade, 2003: 22). 
The low presence of Indigenous people in the prison system is not a problem of course. What I argue here is that this apparent absence, in fact, is not absence, but an intentional operation of ethnic non-recognition that results in the invisibility of Indigenous persons in the criminal justice system. A kind of 'legal invisibility' (Baines, 2016: 124) that accounts for a certain type of statistical insignificance best translated by a famous saying popularized by Mark Twain: 'There are three kinds of lies: lies, damned lies, and statistics.'

Indeed, situations like those addressed above suggests that most of the data referenced in the surveys and databases currently available in Brazil should be undoubtedly analysed with caution. Maggie Walter and Chris Andersen (2013: 10) argue that quantitative methodologies that guide the production and analysis of data on Indigenous peoples reflect and constitute the dominant cultural structure of the nation in which they operate. In the case of the interaction between the Xakriabá people and the criminal justice system of the judicial district of Manga, the instruments for collecting and producing data on police incidents, legal cases and admissions to the prison system, when applied to the Xakriabá, not only reflect, but reaffirm and reinforce the hegemonic orientation for the non-recognition of their self-assertion as a discrete Indigenous collective within the regional racial-ethnic framework.

\section{Old conclusions for (relatively) new problems}

In the pages above I have tried to address some of the most prominent and problematic topics when discussing the issue of criminalization and imprisonment of Indigenous people in Brazil, drawing specifically on the case of the Xakriabá people. I briefly reviewed the domestic legislation and international framework in force, and introduced some of the experiences I had during the fieldwork I conducted in Minas Gerais, bringing the voices of both the agents of the criminal justice system and the Indigenous people submitted to it. After this analytical itinerary, my reflections arrive at the semantic paradox that defines the discussion: the 'integrated Indian', contrary to what this supposed integration would suppose, is being kept by the criminal justice system outside the legal protection afforded to Indigenous peoples by law, in an unconstitutional movement of disaggregating the consensual substantive for political articulation of indigeneity - the term Indian, or Indigenous person - into an artificial duality that establishes two contrastive ontological categories: 'Indians who are still Indians' and 'Indians who are no longer Indians'.

The subject of rights indio, in this sense, would only cover persons and peoples whose authenticity has been validated by those 'authorized identity distributors' (Viveiros de Castro, 2008), leaving those considered 'acculturated' or 'integrated' outside the normative content of the legal protection. The 'integrated' Indian becomes an outlaw: out of the law that defines, without particularly defining, who can be considered Indigenous in Brazil. It is possible to argue, as a conclusion for this piece, that the twentieth century and its democratic order, the judiciary and its 'rule of law', do no more than to revive and update the Manichaean binarity of colonial, imperial, old republican and dictatorial times. What they are doing, in fact, is to wear with brand new discursively democratic clothes the pervasive coloniality that has always defined the relationship between states and Indigenous peoples in Brazil.

Received: January 29, 2021

Approved: October 25, 2021 


\section{References}

ANDRADE, Vera Regina Pereira de. 2003. Sistema penal máximo x cidadania mínima: códigos da violência na era da globalização. Porto Alegre: Livraria do Advogado Editora.

ARAÚJO, Ana Valéria; LEITÃO, Sérgio. 2012. "Direitos indígenas: avanços e impasses pós-1988”. In: A.C.S. Lima and M. Barroso-Hoffman (orgs.), Além da Tutela: Bases para uma nova Política Indigenista III. Rio de Janeiro: Contra-Capa. pp. 23-33.

ASSOCIAÇÃO BRASILEIRA DE ANTROPOLOGIA (ABA); Procuradoria Geral da República (PGR). 2008. Criminalização e Situação Prisional de Índios no Brasil. Edital Projeto de Pesquisa ESMPU n. /2006. Brasília: Relatório Final, ABA.

BAINES, Stephen Grant. 2016. "Disrespecting Indigenous rights in the prison system of Roraima state, Brazil”. Études rurales, 196: 109-126. Available at: https:/|tinyurl.com/y95formj (accessed 6 July 2020).

BRASIL. 1973. Lei 6.001, de 19 de dezembro de 1973 (Estatuto do Índio). Brasília, Brasil.

BRASIL. 1988. Constituição da República Federativa do Brasil. Brasília, Brasil.

BRASIL. 2004. Decreto n. 5.051, de 19 de abril de 2004 (Promulga a Convenção no 169 da Organização Internacional do Trabalho - OIT sobre Povos Indígenas e Tribais). Brasília, Brasil.

CASTILHO, Ela Wiecko Volkmer. 2019. “Indígenas na Prisão: o déficit da perspectiva intercultural”. In: A.C. Oliveira and E.W.V. Castilho (orgs.), Lei do branco ou lei do índio - quem decide?. Rio de Janeiro: Lumen Juris. pp. 127-156.

CASTRO, Eduardo Viveiros de. 2008. “No Brasil todo mundo é índio, exceto quem não é”. In: E. Sztutman (org.), Encontros. Rio de Janeiro: Azougue Editorial. pp. 130-161.

Conselho Nacional de Justiça - CNJ. 2019. Resolução no. 287, de 25 de junho de 2019, available at https:/|atos.cnj. jus.br/atos/detalhar/2959 (accessed 25 August 2021).

COLI, Jorge. 2013. "Fabricação e promoção da brasilidade: arte e questões nacionais". Perspective [online], 2: n/p, Available at https://tinyurl.com/yc7spgkr (accessed 10 June 2020).

COSTA E SANTOS, Rafael Barbi. 2010. A cultura, o segredo e o índio: diferença e cosmologia entre os Xakriabá de São João das Missões/MG. Dissertação de Mestrado em Antropologia Social, Universidade Federal de Minas Gerais, Belo Horizonte.

CUNHA, Manuela Carneiro da. 1992. "Política indigenista no século XIX". In: M.C. Cunha (org.), História dos índios no Brasil. São Paulo: Companhia das Letras. pp. 133-154.

CUNHA, Manuela Carneiro da. 2012. Índios no Brasil: História, Direitos e Cidadania. São Paulo: Claro Enigma.

CUNHA, Manuela Carneiro da. 2017. "Etnicidade: da cultura residual mas irredutível”. In: Cultura com aspas. São Paulo: Ubu. pp. 239-249.

DA SILVA, Cássio Alexandre. 2014. A natureza de um território no sertão do norte de Minas Gerais: a ação territorial dos Xakriabá. Tese de Doutorado em Ciências Humanas, Universidade Federal de Uberlândia, Uberlândia.

FARIA, Rodrigo Arthuso Arantes. 2021. Temas da interação entre o Sistema de Justiça Criminal e o Povo Xakriabá no norte de Minas Gerais. Dissertação de Mestrado em Ciências Sociais, Universidade de Brasília, Brasília.

FERREIRA DOS SANTOS, Ariclenes Ferreira; OLIVEIRA, Aparecido Rodrigues de. 2107. A memória da luta pela terra indígena do povo Xacriabá de Rancharia (MG). Trabalho de Conclusão de Curso (Licenciatura), Faculdade de Educação, Universidade Federal de Minas Gerais, Belo Horizonte.

HEEMANN, Thimotie Aragon. 2017. "Por uma leitura do Direito dos Povos Indígenas: do integracionismo ao interculturalismo". Revista de Doutrina e Jurisprudência, 109(1): 01-14. Available at https:/tinyurl.com/ yblbk6ed (accessed 10 June 2020). 
MARCATO, Sônia de Almeida. 1987. “Remanescentes Xakriabá em Minas Gerais”. Arquivos do Museu de História Natural, 3: 391-426. Available at http://www.etnolinguistica.org/biblio:marcato-1978remanescentes (accessed 22 April 2021).

MENEZES, Gustavo Hamilton. 2016. "O conceito de aculturação indígena na antropologia e na esfera jurídica”. In: J. Melo et al. (orgs.), Ensaios sobre justiça, reconhecimento e criminalidade. Natal: EDUFRN, ABA Publicações. pp. 519-540.

MENEZES, Gustavo Hamilton. 2017. "Doing Field Work with Indigenous People in Brazilian Prisons". Sociology and Anthropology, 5(8): 584-589. Available at https:/|tinyurl.com/y7qc4pcq (accessed 17 July 2020).

MILLER, Bruce Granville. 2003. Invisible Indigenes: The Politics of Nonrecognition. Lincoln: University of Nebraska Press.

MONTEIRO, John Manuel. 2000. "The Heathen Castes of Sixteenth-Century Portuguese America: Unity, Diversity, and the Invention of the Brazilian Indians". Hispanic American Historical Review, 80(4): 697-719. Available at https:/|tinyurl.com/yb3gngn 4 (accessed 10 June 2020).

MOSCOVICI, Serge. 1984. "The Phenomenon of Social Representations". In: Social representations. Cambridge: Cambridge University Press. pp. 3-69.

Organization of American States - OAS. 2016. American Declaration on the Rights of Indigenous Peoples. Santo Domingo, Dominican Republic.

OLIVEIRA, Roberto Cardoso de. 2003. "Identidade étnica, identificação e manipulação". Sociedade e Cultura, 6(2): 113-131. Available at https://tinyurl.com/yanxma8n (accessed 10 June 2020).

PACHECO DE OLIVEIRA, João. 2016. "Uma etnologia dos "índios misturados"? Situação colonial territorialização e fluxos culturais". In: O nascimento do Brasil e outros ensaios: "pacificação", regime tutelare formação de alteridades. Rio de Janeiro: Contra Capa. pp. 193-228.

PACHECO DE OLIVEIRA, João; FREIRE, Carlos Augusto da Rocha. 2006. A Presença Indígena na Formação do Brasil. Rio de Janeiro: LACED/Museu Nacional.

PEREIRA, Deborah Macedo Duprat de Britto. 2012. "O Estado pluriétnico”. In: Lima, A.C.S. Lima; Maria Barroso-Hoffmann (orgs.), Além da Tutela: Bases para uma nova Política Indigenista III. Rio de Janeiro: Contra-capa. pp. 41-47.

PERRONE-MOISÉS, Beatriz. 1992. “Índios livres e índios escravos. Os princípios da legislação indigenista do período colonial (séculos XVI a XVIII)”. In: M.C. Cunha (org.), História dos índios no Brasil. São Paulo: Companhia das Letras. pp. 115-132.

POVINELLI, Elizabeth. 1998. "The Cunning of Recognition: Real Being and Aboriginal Recognition in Settler Australia". Australian Feminist Law Journal, 11(1): 3-27. Available at: https:/|tinyurl.com/yezaxksf (accessed 23 March 2021).

RAMINELLI, Ronald. 1996. Imagens da colonização. A representação do índio de Caminha a Vieira. Rio de Janeiro: Zahar.

RAMOS, Alcida Rita. 2018. "O indigenismo na montagem da nação Contrastes e convergências entre Brasil e Argentina”. Anuário Antropológico, 33(1): 27-59. Available at: https:/|tinyurl.com/y7mgfg 4 n (accessed 29 May 2020).

ROBERTO OLIVEIRA, Antônio. 2008. Política e políticos indígenas: a experiência Xakriabá. Dissertação de Mestrado em Antropologia Social, Universidade de Brasília, Brasília.

SANTOS, Ana Flávia Moreira. 1997. Do terreno dos caboclos do Sr. São João à Terra Indígena Xakriabá: as circunstâncias da formação de um povo. Um estudo sobre a construção social de fronteiras. Dissertação de Mestrado em Antropologia Social, Universidade de Brasília, Brasília. 
SILVA, Cristhian Teófilo. 2014. "O índio, o pardo e o invisível: primeiras impressões sobre a criminalização e o aprisionamento de indígenas no Brasil”. Antropolítica, 34: 137-158. Available at: https:|/tinyurl.com/ yclk6b4m (accessed 29 May 2020).

SILVA, Cristhian Teófilo. 2016. "Regimes de indianidade, tutela coercitiva e estadania: examinando a violência institucional contra indígenas no Brasil e no Canadá”. Espaço Ameríndio, Porto Alegre, 10(2): 194-222. Available at https://seer.ufrgs.br/EspacoAmerindio/article/view/67841 (accessed 14 May 2021).

SOUZA FILHO, Carlos Frederico Marés. 1999. O renascer dos Povos Indígenas para o Direito. Curitiba: Juruá.

SUAREZ, Joana; TAVARES, Flávio. 2020. Terra indígena Xakriabá: fome, seca e resistência. Available at https:/| www.youtube.com/watch?v=3IXztrlHXUM\&t=6s (accessed 28 April 2021).

TACCA, Fernando. 2011. "O índio na fotografia brasileira: incursões sobre a imagem e o meio". História, Ciências, Saúde - Manguinhos, 18(1): 191-223. Available at https:/|tinyurl.com/ybloo6dt (accessed 10 June 2020).

United Nations. 2007. United Nations Declaration on the Rights of Indigenous Peoples. Available at https:/|tinyurl. com/37x2n3ds (accessed 28 August 2021).

VILLARES, Luiz Fernando. 2009. Direito e Povos Indígenas. Curitiba: Juruá.

VILLARES, Luiz Fernando. (Coord.). 2010. Direito penal e povos indígenas. Curitiba: Juruá.

WALTER, Maggie; ANDERSEN, Chris. 2013. Indigenous statistics: a quantitative research methodology. Walnut Creek: Left Coast Press.

ZACKSESKI, Cristina. 2016. "Dimensões do encarceramento e desafios da política penitenciária no Brasil”. Revista Brasileira de Ciências Criminais, 126: 291-331. Available at https:/|tinyurl.com/ycfbpyyv (accessed 10 June 2020).

\section{Rodrigo Arthuso Arantes Faria}

University of British Columbia (UBC)

Department of Anthropology

Vancouver Campus

Vancouver, British Columbia, Canada

https://orcid.org/oooo-0002-0254-1711

E-mail: rodrigoaafaria@gmail.com 